\title{
PERANAN METODE BERMAIN PERAN DAN MEDIA VIDEO (LCD) DALAM MENINGKATKAN HASIL BELAJAR BAHASA INDONESIA TEMA CERITA RAKYAT KELAS V SEKOLAH DASAR NEGERI PASIRGUNUNG SELATAN 4 KOTA DEPOK.
}

\author{
Nama : Sugiyarti \\ Nim: 836366609 \\ Email: sugiyarti341@gmail.com
}

\begin{abstract}
ABSTRAK
Tujuan utama PTK ini adalah Peranan Metode Bermain Peran dan Media Video (LCD) dalam Meningkatkan Hasil Belajar Bahasa Indonesia Tema Cerita Rakyat kelas V SDN Pasirgunung Selatan 4 Kota Depok. Penelitian Tindakan Kelas dilaksanakan di SDN Pasirgunung Selatan 4 Kecamatan Cimanggis, Kota Depok dengan jumlah 38 orang peserta didik kelas V. Pada pembelajaran Prasiklus diperoleh nilai rata-rata kelas 66 peserta didik yang tuntas dalam belajar hanya berjumlah 20 (53\%) peserta didik. Sedangkan hasil pengamatan menunjukkan bahwa sebanyak 17 (45\%) peserta didik dapat menjawab dengan benar. Pada siklus 1 nilai rata-rata 69. Peserta didik mencapai ketuntasan sebanyak 22 (58\%). Sedangkan hasil pengamatan menunjukkan bahwa sebanyak 25 (66\%) dapat menjawab dengan benar. Pada siklus 2 diperoleh rerata kelas 80. Peserta didik yang tuntas dalam belajarnya sebanyak 30 (80\%). Sedangkan hasil pengamatan yang dapat menjawab dengan benar pertanyaan guru sebanyak 32 (84\%). Dengan demikian penerapan Bermain peran dan alat peraga Video telah memberikan pengaruh yang sangat baik dengan meningkatkan hasil belajar dan motivasi peserta didik materi yang disampaikan dimengerti peserta didik, Tanggung jawab peserta didik terhadap tugas tinggi, serta membantu peserta didik untuk terlibat akhir didalam kelas.
\end{abstract}

Kata Kunci: Hasil belajar Bahasa Indonesia, Bermain Peran, Video (LCD)

\section{PENDAhUluan}

\section{A. Latar Belakang Masalah}

Pendidikan sekolah dasar bukan hanya memberikan bekal kemampuan pengetahuan saja tetapi juga sikap, dan keterampilan sebagai proses pengembangan sosial dan personal yang pokok untuk melanjutkan atau mengikuti pendidikan ke jenjang yang lebih tinggi. Mata pelajaran Bahasa Indonesia merupakan mata pelajaran yang resmi di negara kita. Bahasa Indonesia ini sudah menjadi bahasa pemersatu dan bahkan sudah tertuang dalam sebuah sumpah, yaitu Sumpah Pemuda. Dalam pembelajaran ini peserta didik diharuskan mencapai Kriteria Ketuntasan Minimum (KKM). Dalam artian peserta didik harus memahami dan mendapatkan nilai sesuai KKM. Karena KKM dapat dijadikan sebagai tolak ukur keberhasilan peserta didik dalam menerima pembelajaran. 
Pada kenyataannya, Bahasa Indonesia dianggap ilmu yang sangat luas oleh peserta didik dikelas V SDN Pasirgunung Selatan 4 Cimanggis Depok. Prestasi belajar peserta didik kelas $\mathrm{V}$ dalam pelajaran Bahasa Indonesia materi cerita rakyat belum mencapai Kriteria Ketuntasan Minimum ( KKM ) yang harus dicapai yaitu 70. Pada pembelajaran prasiklus didapat nilai rata-rata kelas 66. Peserta didik yang tuntas dalam belajar hanya berjumlah 19 orang dari 38 peserta didik atau 50\% dan yang belum mencapai ketuntasan belajar sebanyak 19 orang dari 38 peserta didik atau 50\%.

Berdasarkan peneliti mengupayakan nilai rata-rata kelas pada prasiklus dapat memperbaiki dan meningkatkan hasil yang lebih baik, peneliti melakukan Penelitian Tindakan Kelas. Penelitian ini dilakukan dalam beberapa siklus, setiap siklus diharapkan mendapat perubahan dan peningkatan yang lebih baik. Dengan bantuan guru sebagai teman sejawat penulis mengadakan refleksi untuk mencari permasalahan yang di anggap serius dalam proses pembelajaran.

Agar pembelajaran Bahasa Indonesia dapat memberikan pengalaman yang lebih bermakna serta tidak membosankan sehingga mencapai hasil belajar yang maksimal sesuai dengan tujuan yang diharapkan, maka harus memilih media dan metode pembelajaran yang sesuai dengan karakteristik dan kemampuan peserta didik. Dengan metode dan pembelajaran yang sesuai pula peserta didik dapat menjadi lebih kritis dan kreatif ,mampu bekerja sama,mampu berpikir logis,analisis dan sistematis.

Untuk memperbaiki pembelajaran dan meningkatkan pencapaian hasil yang diharapkan, peneliti merasa perlu melakukan Penelitian Tindakan Kelas (PTK). Dengan merefleksi bersama antar guru maka akan teridentifikasi akar permasalahan. Proses pembelajaran yang selama ini hanya didominasi guru, menonton hanya menggunakan metode ceramah diubah menjadi pembelajaran yang menyenangkan bagi peserta didik untuk peningkatan pemahaman melalui siklus yang setiap siklusnya dengan langkah perencanan, pelaksanaan, pengamatan atau observasi dan refleksi pembelajaran.

Berdasarkan kenyataan tersebut,maka perlu kiranya dilakukan upaya penelitian untuk meningkatkan kemampuan peserta didik pada materi cerita rakyat melalui Penelitian Tindakan Kelas ( PTK ) yang dibantu oleh teman sejawat. Penulis bersama teman sejawat mengadakan diskusi untuk mencari temuan masalah. 


\section{Indentifikasi Masalah}

Dari hasil observasi dan diskusi teman sejawat maka masalah yang menjadi faktor penyebab kurang optimalnya proses pembelajaran sehingga perlu dilakukan perbaikan.

Adapun beberapa masalah tersebut antara lain :

a) Rendahnya nilai hasil belajar peserta didik yang dibawah KKM.

b) Peserta didik kurang memahami pelajaran Bahasa Indonesia tentang penjelasan guru dengan materi cerita rakyat.

c) Peserta didik dikelas V SDN Pasirgunung Selatan 4 cenderung pasif dan kurang tertarik pada pelajaran Bahasa Indonesia materi cerita rakyat.

d) Peserta didik sering tidak fokus disaat guru memberikan materi pelajaran.

e) Peserta didik tidak menjawab pertanyaan guru dengan benar.

\section{Analisis Masalah.}

Setelah mengidentifikasi masalah, selanjutnya perlu dilakukan analisis dengan cara merefleksi hasil evaluasi siswa.

Adapun faktor-faktor penyebab rendahnya aktivitas belajar dan kemampuan siswa pada materi cerita rakyat adalah :

a) Guru belum menggunakan metode dan media pembelajaran yang menarik.

b) Guru kurang memotivasi kepada peserta didik dalam proses pembelajaran.

c) Guru tidak melibatkan peserta didik ketika menjelaskan materi.

d) Guru terlalu cepat dalam menjelaskan materi.

\section{Alternatif dan Prioritas pemecahan Masalah.}

Dari analisis masalah diatas, penulis menemukan alternatif dan prioritas pemecahan masalah sebagai berikut :

a) Dalam penyampaian materi guru harus menggunakan metode dan media yang menarik, tepat, mudah dipahami agar pembelajaran jadi menyenangkan.

b) Guru harus dapat memotivasi terhadap seluruh peserta didik.

c) Guru harus melibatkan seluruh peserta didik dalam proses pembelajaran.

d) Dalam menjelaskan materi guru harus perlahan-lahan dan dapat dipahami peserta didik.

Jadi, penggunaan metode pembelajaran dan penggunaan media pembelajaran yang kurang tepat dapat mempengaruhi hasil belajar siswa. 
Oleh karena itu, dalam Penelitian Tindakan Kelas ini, penulis mencoba meneliti tentang metode yang bervariasi dan media pembelajaran yang tepat untuk meningkatkan pemahaman siswa pada pelajaran Bahasa Indonesia tentang cerita rakyat dikelas $\mathrm{V}$.

\section{B. Rumusan Masalah}

Dari identifikasi masalah, analisis masalah dan prioritas pemecahan masalah yang telah diuraikan diatas, dapat dirumusan poko rumusan masalah adalah : "Bagaimana Peranan Metode Bermain Peran dan Media Video (LCD) dalam meningkatkan hasil belajar Bahasa Indonesia Tema Cerita Rakyat kelas V SDN Pasirgunung Selatan 4 Kota Depok?".

\section{Tujuan Penelitian Perbaikan Pembelajaran}

Demi tercapainya keberhasilan dalam pencapaian pembelajaran Bahasa Indonesia, maka penulis sebagai pendidik dan pengajar untuk melakukan Perbaikan pembelajaran melalui Penelitian Tindakan kelas (PTK) yang bertujuan untuk meningkatkan hasil belajar Bahasa Indonesia di SDN Pasirgunung Selatan 4 menggunakan metode bermain peran dan media Video (LCD).

\section{Manfaat Hasil Penelitian}

Banyak manfaat yang diperoleh setelah melakukan perbaikan pembelajaran pada pelajaran Bahasa Indonesia antara lain :

\section{Bagi Peserta didik :}

a. Meningkatkan minat membaca peserta didik pada muatan pelajaran Bahasa Indonesia

b. Memudahkan pemahaman peserta didik terhadap materi cerita rakyat

c. Meningkatkan hasil belajar siswa

\section{Bagi Guru :}

a. Meningkatkan profesionalisme guru dalam melaksanakan pembelajaran dikelas

b. Meningkatkan kreatifitas guru dalam penggunaan media dan metode pembelajaran

c. Memahami permasalahan yang dihadapi peserta didik 


\section{Bagi Kepala Sekolah :}

a. Meningkatkan kualitas pembelajaran di SDN Pasirgunung Selatan 4 Cimanggis Depok

b. Menginspirasi guru-guru lainnya yang ada disekolah agar lebih inovatif dalam penggunaan media dan metode

\section{Manfaat Hasil Penelitian :}

a. Sebagai pengalaman berharga bagi peneliti dalam mengaplikasikan ilmu pengetahuan sehingga akan memperkaya pengetahuan penelitian untuk diamalkan

b. Sebagai bahan acuan untuk peneliti agar menjadi lebih baik pada saat melakukan pembelajaran.

\section{KAJIAN PUSTAKA}

\section{A. Hasil Belajar Bahasa Indonesia}

\section{Hasil Belajar}

Belajar merupakan menambah dan mengumpulkan pengetahuan. Menurut Ernest R. Hilgard, belajar merupakan proses perubahan tingkah laku yang diperoleh melalui latihan. Perubahan itu disebabkan karena ada dukungan dari lingkungan yang positif yang menyebabkan terjadinya interaksi edukatif. Hasil belajar merupakan kulminasi dari suatu proses yang telah dilakukan dalam belajar. Menurut Anitah (2014:219). Hasil belajar merupakan refleksi keleluasaan, kedalaman, kompleksitas dan digambarkan secara jelas serta dapat diukur dengan teknik-teknik penilaian tertentu. Hasil belajar tampak terjadinya perubahan tingkah laku pada diri siswa yang dapat diamati, diukur dalam perubahan pengetahuan, sikap, dan keterampilan. Oleh karena itu penilaian hasil belajar mempunyai peranan yang penting dalam proses belajar.

Selanjutnya menurut Suprijono (2009:5-7) hasil belajar berupa pola-pola perbuatan, nilai-nilai, pengertian-pengertian, apresiasi dan keterampilan. Merujuk pemikiran Gagne dalam Suprijono (2009:5-6) hasil belajar berupa :

1) Informasi verbal yaitu kapabilitas mengungkap pengetahuan dalam bentuk bahasa, baik lisan maupun tertulis.

2) Keterampilan intelektual yaitu kemampuan mempresentasikan konsep dan lambang. 
3) Strategi kognitif yaitu kecakapan menyalurkan dan mengarahkan aktifitas kognitifnya sendiri.

4) Keterampilan motorik yaitu keterampilan melakukan serangkaian gerak jasmani dalam urusan koordinasi, sehingga terwujud otomatisme gerak jasmani.

5) Sikap adalah kemampuan menerima atau menolak objek berdasarkan penilaian terhadap objek tersebut.

Menurut Bloom dalam Suprijono (2009:6), hasil belajar mencangkup kemanpuan kognitif, afektif dan psikomotor. Domain kognitif adalah knowledge (pengetahuan, ingatan), comprehension (pemahaman, menjelaskan, meringkas, contoh), application (menerapkan), analysis (menguraikan, menentukan hubungan), synthesis (mengorganisasikan, merencanakan, membentuk bangunan baru), dan evaluation (menilai). Domain efektif adalah receiving (sikap menerima), responding (memberikan respon), valuing (nilai), organization (organisasi), characterization (karakterisasi). Domain psikomotor meliputi intitiatory, pre-routine, dan rountinized. Selain itu psikomotor mencangkup keterampilan produktif, teknik, fisik, sosial, manajerial, dan intelektual.

Jadi hasil belajar adalah peribahan perilaku secara keseluruhan bukan hanya salah satu aspek potensi kemanusiaan saja. Artinya hasil pembelajaran yang dikategorisasi oleh para pakar pendidikan tidak dilihat secara terpisah melainkan komprehensif.

\section{Bahasa Indonesia SD}

Menurut Mulyati (2015:13) "Hakikat bahasa dilihat dari aspek bunyi/isyarat, simbol (huruf/gambar), dan makna. Dari ketiga aspek ini dapat didefinisikan bahwa "bahasa" adalah suatu bunyi ujaran/isyarat yang dapat disimbolkan melalui huruf/gambar yang berbeda-beda, masing-masing bunyi/isyarat dan simbol/gambar tersebut memiliki makna yang berbeda-beda pula".

Selanjutnya menurut Mulyati Bahasa merupakan sarana untuk saling berkomunikasi, saling berbagi pengalaman, saling belajar dari yang lain, serta untuk meningkatkan pengetahuan intelektual dan kesusastraan merupakan salah satu sarana untuk menuju pemahaman tersebut. Standar kompetensi mata pelajaran Bahasa Indonesia adalah program untuk mengembangkan pengetahuan, keterampilan 
berbahasa, dan sikap positif terhadap Bahasa Indonesia, serta menghargai manusia dan nilai-nilai kemanusiaan.

Fungsi Mata Pelajaran Bahasa Indonesia adalah sebagai berikut:

1) Sarana pembinaan kesatuan dan kesastraan Bangsa

2) Sarana peningkatan pengetahuan dan keterampilan dalam rangka pelestarian dan pengembangan budaya

3) Sarana peningkatan pengetahuan dan keterampilan untuk meraih dan mengembangkan ilmu pengetahuan, teknologi dan seni.

4) Sarana pengembangan penalaran

5) Sarana pemahaman beragam budaya Indonesia melalui khazanah kesusastraan Indonesia.

Manfaat pembelajaran Bahasa Indonesia menurut Sri Wintala Achmad (2015:22) adalah sebagai berikut:

1) Sebagai media Berkomuniksi

2) Sebagai media mempelajari Ilmu Pengetahuan

3) Sebagai media Penyampaian ide kreatif

4) Sebagai media utama dalam penyuntingan naskah

5) Sebagai Bahasa Nasional, Persatuan, dan Negara

Dengan demikian Pembelajaran Bahasa Indonesia di SD suatu bentuk komunikasi lisan antara peserta didik yang terpola melalui keterampilan menyimak, berbicara, membaca dan menulis sehingga Suasana pembelajaran terhindar dari kejenuhan.

- Pembelajaran menyimak

Menyimak merupakan keterampilan berbahasa yang pertama kali dikuasai oleh manusia sebelum menguasai keterampilan berbicara, membaca, dan menulis.

- Pembelajaran membaca

Di kelas 1 dan 2 SD pelajaran membaca ditekankan pada mekanisme, artinya mengubah lambang-lambang tertulis menjadi bunyi-bunyi yang bermakna, sedangkan di kelas 3 samapi kelas 6 pelajrn membaca lebih ditekankan pada kegiatan membaca lanjut mulai dari teknik membaca, membaca dalam hati, membaca cepat, membaca bahasa, dan membaca indah. 
- Pembelajaran membaca

Berbicara adalah kemampuan mengucapkan kata untuk mengekspresikan, menyatakan serta menyampaikan pikiran, gagasan, dan perasaan.

- Pembelajaran menulis

Menurut Tarigan (1992) mengemukakan bahwa menulis adalah menuliskan lambang-lambang grafik yang menggambarkan suatu bahasa yang dipahami oleh seseorang sehingga orang lain dapat membaca lambang-lambang grafik tersebut apabila mereka memahami bahasa dan grafik tersebut.

\section{B. Metode Bermain Peran (Role playing)}

Role Playing atau Bermain peran adalah pembelajaran bahasa yang berprinsip komunikasi yang dapat menimbukan hubungan situasi sosial dalam kegiatan pembelajaran sehingga dapat meningkatkan keaktifan siswa dalam penggunaan Bahasa secara lisan yang mengandung arti atau makna Amiruddin (2019:95). Dalam Role Playing murid dikondisikan pada situasi tertentu diluar kelas meskipun saat itu pembelajaran terjadi didalam kelas. Selain itu, Role Playing sering kali dimaksudkan sebagai suatu bentuk aktifitas dimana pembelajar membayangkan dirinya seolah-olah berada diluar kelas dan memainkan peran orang lain.

“Chasler (1966:75) buku model-model pembelajaran mengatakan, these parts people play are called roles. A role is" a patterned sequence of feelings, word, and actions...It is a unique and accustomed manner of relating to athers". Bagian-bagian orang bermain disebut peran. Peran adalah" urutan bermotif perasaan, kata-kata, dan tindakan ini adalah cara yang unik dan terbiasa berhubungan dengan orang lain. Jadi dalam model pembelajaran bermain peran sangat ditekankan pada peserta didik menggunakan perasaan dengan baik, kata-kata yang tegas dan yang lebih penting adalah penghayatan karakter tokoh yang diperankan dengan tujuan mmenimbulkan tingkah laku yang sempurna dalam action pemeran".

Shaftel (1967) mengungkapkan" in role playing, students explore human relations problems by enacting problem situations and then discussing the enactments. Together, students can explore feelings, attitudes, values, and problem-solving strategies. Dalam bermain peran, peserta didik mengeksplorasi masalah hubungan manusia dengan memberlakukan situasi masalah, kemudian mendiskusikan enactments (keadaan atau 
situasi atau hukum yang berlaku) secara bersama, peserta didik dapat mengeksplorasi perasaan, sikap, nilai, dan strategi pemecahan masalah.

Pembelajaran ini pada umumnya dilakukan lebih dari satu orang. Metode bermain peran titik tekanannya terletak pada keterlibatan emosional dan pengamatan indera kedalam suatu situasi masalah yang secara nyata dihadapi. Langkah Metode Pembelajaran Role Playing adalah sebagai berikut :

a. Menyusun atau mempersiapkan scenario yang akan ditampilkan

b. Menunjuk beberapa peserta didik untuk mempelajari skenario dalam waktu beberapa hari sebelum pelaksanaan kegiatan belajar mengajar

c. Guru membentuk kelompok peserta didik untuk memerankan skenario ke depan kelas

d. Memberikan penjelasan tentang kompetensi yang ingin dicapai

e. Memanggil para peserta didik yang sudah ditunjuk untuk melakukan skenario yang sedang diperagakan

f. Setelah ditampilkan masing-masing peserta didik diberikan lembar evaluasi.

Menurut Suprijono (2019:84) Keunggulan Metode pembelajaran Bermain peran (Role playing), diantaranya adalah :

1. Dapat berkesan dengan kuat dan tahan lama dalam ingatan peserta didik

2. Meningkatkan motivasi dan semangat dalam diri peserta didik serta menumbuhkan rasa kebersamaan

3. Menjadikan kelas dinamis dan antusias

4. Peserta didik belajar secara aktif dengan memerankan sesuatu yang akan dibahas dalam proses belajar.

Kelemahan Metode pembelajaran Bermain peran (Role playing), diantaranya adalah :

1. Bermain peran memakan waktu yang lama

2. Peserta didik sering mengalami kesulitan untuk memerankan peran secara baik

3. Jika peserta didik dan kelas tidak dipersiapkan dengan baik ada kemungkinan peserta didik tidak akan melakukan dengan sunguh-sungguh

4. Tidak semua materi pelajaran didapat disajikan melalui metode ini

Menurut Fathurrohman (2015:93), bermain peran ( Role Playing) pada prinsipnya merupakan metode untuk menghadirkan peran-peran yang yang ada dalam dunia nyata 
kedalam suatu pertunjukan peran didalam kelas. Dapat penulis simpulkan bahwa, metode bermain peran merupakan suatu pembelajaran bahasa yang berprinsip pada kamunikasi yang dapat menimbulkan hubungan situasi sosial dalam kegiatan pembelajran sehingga dapat meningkatkan keaktifan siswa dalam penggunaan bahasa secara lisan yang mengandung arti atau makna.

\section{Media Pembelajaran Penayangan Video}

\section{Media Pembelajaran}

Media artinya perantara atau pengantar, media adalah segala alat fisik yang dapat menyajikan pesan yang merangsang untuk belajar, misalnya media cetak, media elektronik (film dan video). Dalam arti luas, media adalah kegiatan yang dapat menciptakan suatu kondisi, sehingga memungkinkan peserta didik dapat memperoleh pengetahuan, keterampilan, dan sikap yang baru.

Menurut Heinich, dkk (1993) media pembelajaran "media merupakan alat saluran komunikasi. Media berasal dari bahasa latin dan merupakan bentuk jamak dari kata"medium" yang secara harfiah berarti "perantara" yaitu perantara sumber pesan (a source) dengan penerimaan pesan (a receiver)'”. Heinich mencontohkan media ini seperti film, televisi, diagram, bahan tercetak (printed materials), computer dan instruktur.

Menurut Gagne, Media adalah berbagai jenis komponen dalam lingkungan perserta didik yang dapat merangsang peserta didik untuk belajar.

Kegiatan pembelajaran itu sendiri pada hakikatnya merupakan komunikasi. Guru berperan sebagai komunikator yang bertugas menyampaikan informasi kepada peserta didik. Peserta didik berperan sebagai penerima pesan. Supaya pesan atau materi pelajaran yang disampaiakn guru dapat diterima oleh peserta didik maka diperlukan tempat penyalur pesan yaitu media pembelajaran.

Dalam sistem pembelajaran modern ini,peserta didik tidak hanya berperan sebagai komunikasi atau penerima pesan, bisa saja peserta didik bertindak sebagai komunikator atau penyampai pesan. Dalam bentuk komunikasi pembelajaran manapun sangat dibutuhkan peran media untuk lebih meningkatkan tingkat keefektifan pencapaian tujuan/ kompetensi. Artinya, proses pembelajaran tersebut akan terjadi apabila ada komunikasi antara penerima pesan dengan sumber/ penyalur pesan lewat media tersebut. 
Adapun manfaat media pembelajaran menurut Kemp dan Dayton (1985) yang dikutip oleh Azhar Arsyad adalah sebagai berikut :

1) Penyampaian pelajaran menjadi lebih baku

2) Pembelajaran lebih menarik

3) Pembelajaran menjadi lebih interaktif

4) Waktu pembelajaran dapat dipersingkat

5) Kualitas hasil belajar dapat ditingkatkan

6) Peran guru dapat berubah ke arah yang lebih positif .

\section{Media video}

Menurut Daryanto (2015:4) “Video adalah suatu medium yang sangat efektif untuk membantu proses pembelajaran,baik untuk pembelajaran masal, individual, maupun berkelompok". Video juga merupakan bahan ajar non cetak yang kaya informasi dan tuntas karena dapat sampai kehadapaan peserta didik secara langsung. Disamping itu, video menambah suatu dimensi baru terhadap pembelajaran.

Media video adalah segala sesuatu yang memungkinkan sinyal audio dapat dikombinasikan dengan gambar bergerak secara sekuensial program. Video dapat dimanfaatkan dalam program pembelajaran karena dapat memberikan pengalaman yang tidak terduga kepada peserta didik.

Hal ini karena karakteristik teknologi video yag dapat menyajikan gambar bergerak pada peserta didik, disamping suara yang menyertainya. Dengan demikian,peserta didik merasa seperti berada di suatu tempat yang sama dengan program yang ditayangkan video. Seperti anda ketahui bahwa tingkat relensi (daya serap dan daya ingat) peserta didik terhadap materi pelajaran dapat meningkat secara signifikan jika proses pemerolehan informasi awalnya lebih besar melalui indra pendengaran dan penglihatan.

Manfaat dari media video ini adalah:

- Membantu memberikan kesan yang benar

- Mendorong minat belajar peserta didik

- Meningkatkan pengertian yang lebih baik

- Menambah variasi metode mengajar 
Berdasarkan pada media video ini disimpulkan bahwa menggunakan media video dapat meningkatkan aktivitas dan hasil belajar peserta didik dalam pembelajaran Bahasa Indonesia dikelas V SDN Pasirgunung Selatan 4 Kota Depok.

\section{Penelitian Tindakan Kelas (PTK)}

Menurut Wardani (2014:1.4),'Penelitian Tindakan Kelas adalah penelitian yang dilakukan oleh guru didalam kelasnya sendiri melalui refleksi diri dengan tujuan untuk memperbaiki kinerja sebagai guru sehingga hasil belajar peserta didik menjadi meningkat".

Menurut Mills (2014:1.4) mendefinisikan Penelitian Tindakan Kelas sebagai "Systematic inquiry" yang dilakukan oleh guru, kepala sekolah, atau konselor sekolah untuk mengumpulkan informasi tentang berbagai praktek yang dilakukannya. Informasi ini digunakan untuk meningkatkan persepsi serta mengembangkan "reflective practice" yang berdampak positif dan berbagai praktek persekolahan, termasuk memperbaiki hasil belajar siswa.

Menurut Hopkins (1993),dalam buku PTK "penelitian kelas dilakukan oleh guru dipandang sebagai satu unjuk kerja seorang guru yang profesional karena studi sistematik yang dilakukan terhadap diri sendiri dianggap sebagai tanda dari pekerjaan guru yang professional".

Manfaat Penelitian Tindakan Kelas (PTK) bagi guru, bagi peserta didik, dan sekolah adalah sebagai berikut:

\section{Manfaat bagi guru}

- PTK dapat dimanfaatkan oleh guru untuk memperbaiki pembelajaran yang dikelolanya.

- Membantu guru berkembang secara profesional

- Meningkatkan rasa percaya diri guru

- Memungkinkan guru secara aktif mengembangkan pengetahuan dan keterampilan.

\section{Manfaat bagi peserta didik}

Untuk meningkatkan hasil belajar peserta didik, disamping guru yang melaksanakan PTK dapat menjadi model bagi para peserta didik dalam bersikap kritis terhadap hasil belajarnya. 


\section{Manfaat bagi sekolah}

PTK membantu sekolah untuk berkembang karena adanya peningkatan pada diri guru dan pendidikan disekolah tersebut.

Langkah-langkah melakukan PTK menurut Asrori (2009:61) adalah sebagai berikut:

1. Mengidentifikasi masalah

2. Menganalisis dan merumuskan masalah

3. Merencanakan PTK

4. Melaksanakan PTK

Dari beberapa pengertian diatas dapat disimpulkan bahwa penelitian melakukan tindakan penelitian yang dilakukan oleh guru didalam kelasnya sendiri melalui refleksi dan dengan tujuan untuk memperbaiki kinerja sebagai guru sehingga hasil belajar peserta didik menjadi meningkat.

\section{PELAKSANAAN PENELITIAN PERBAIKAN PEMBELAJARAN}

\section{A. Subyek, Tempat, Waktu Penelitian dan Pihak yang Membantu.}

\section{Subyek dan Tempat Penelitian.}

Subyek Penelitian Tindakan kelas di pilih dan dilaksanakan berdasarkan tempat penulis bertugas jumlah peserta didik 38 orang dengan laki-laki 19 orang dan perempuan 19 orang peserta didik di kelas V SDN Pasirgunung Selatan 4, Kecamatan Cimanggis, Kota Depok. Tempat yang di gunakan berlokasi di Jln. Pondok pesantren Nurul Huda Kelurahan Pasirgunung Selatan, Kecamatan Cimanggis, Kota Depok.

\section{Waktu Penelitian.}

Pelaksanaan Penelitian Perbaikan Pembelajaran pada Bahasa Indonesia diawali dari perencanaan hingga sampai pada laporan hasil penelitian. Waktu Penelitian Tindakan Kelas berlangsung mulai dari tanggal 22 Juli 2019 s/d 29 Juli 2019. Pelaksanaan Penelitian Tindakan Kelas pada pelajaran Bahasa Indonesia di awali dengan prasiklus pada hari Jum'at tanggal 22 Juli 2019 yang menjadi sumber permasalahan yang ditemui. Kemudian dilanjutkan perbaikan pembelajaran Siklus I pada hari Rabu tanggal 27 Juli 2019 yang merupakan perbaikan pembelajaran tahap pertama setelah prasiklus. 
Selanjutnya Siklus II hari Jum'at tanggal 29 Juli 2019 sebagai perbaikan pembelajaran yang hasilnya diharapkan akan lebih baik.

\section{Pihak yang Membantu Penelitian.}

a) Aswiyah Manis, S.Pd. selaku Kepala SDN Pasirgunung Selatan 4, Cimanggis Depok.

b) Fitriani Soleha, S. Pd. selaku teman sejawat.

\section{B. Desain Prosedur Perbaikan Pembelajaran.}

Agar penelitian memperoleh hasil yang diharapkan dan kegiatan penelitian ini terarah dengan baik, maka penelitian terlebih dahulu melakukan persiapan penelitian. Persiapan penelitian yang dilakukan meliputi hal-hal sebagai berikut :

1. Mengobservasi hal-hal yang akan diteliti, menyiapakan sarana dan pra sarana yang di perlukan.

2. Menentukan kelas yang ada di teliti yaitu kelas V SDN Pasirgunung Selatan 4, Cimanggis Depok

3. Menentukan mata pelajaran yang akan dijadikan obyek penelitian yaitu pelajaran Bahasa Indonesia dengan tema Cerita Rakyat.

4. Menentukan materi pembelajaran yang akan di teliti yaitu Cerita Rakyat.

5. Merancang penelitian tindakan kelas dengan perencanaan tindakan, pelaksanaan, Observasi dan Evaluasi.

Desain Prosedur Pembelajaran yang peneliti lakukan terdiri dari beberapa Siklus yang setiap Siklusnya terdiri dari tahapan, yaitu tahap persiapan sebagai perencanaan, Pelaksanaan, pengamatan atau Observasi dan tahap Refleksi.

Setiap daur atau Siklus dalam penelitian ini memiliki langkah atau tahapan yang sama. Prasiklus dilakukan sebagai usaha mengetahui permasalahan yang menjadi dari latar belakan penelitian tindakan kelas dalam dan dilanjutkan dengan kegiatan Siklus I yang merupakan perbaikan dari prasiklus dan diakhiri pada Siklus Ke II sebagai perbaikan dari Siklus I 
Setelah Peneliti melakukan diskusi dan mempelajari pengamatan yang dilakukan oleh teman sejawat dan mempersiapkan segala yang di butuhkan dalam pelaksanaan perbaikan pembelajaran sebagai langkah dalam penelitian di deskripsikan.

Dalam penelitian ini dilaksanakan dua Siklus yang masing-masing melalui 4 tahapan yaitu Tahap perencanaan, Pelaksanaan pengamatan dan refleksi. Adapun pelaksanaan Penelitian tersebut dideskripsikan sebagai berikut:

\section{Siklus I}

\section{a. Persiapan}

a) Perencanaan Pelaksanaan pembelajaran yang akan dilaksankan pada hari Rabu tanggal 27 Juli 2019

b) Guru menyusun Rencana Pembelajaran Bahasa Indonesia dengan tema cerita rakyat

c) Penyusunan metode pembelajaran berupa ceramah, diskusi, Tanya jawab dan penugasan

d) Persiapan sumber belajar dan bahan ajar berupa cerita bergambar dan buku

e) Penyusunan alat evaluasi pembelajaran atau lembar kerja peserta didik (LKS)

\section{b. Pelaksanaan}

\section{1) Kegiatan Awal (10 menit)}

- Mengajak semua peserta didik berdoa menurut agama dan keyakinan masingmasing

- Melakukan komunikasi tentang kehadiran peserta didik / absen

- Mempersiapkan siswa untuk belajar, guru menarik perhatian peserta didik dengan bertanya kepada peserta didik tentang cerita malin kundang

\section{2) Kegiatan inti (50 menit)}

- Guru menyajikan informasi tentang unsur-unsur dalam cerita

- Peserta didik membaca sebuah cerita rakyat yang ada dibuku

- Peserta didik menyebutkan tokoh, watak, latar dan amanat cerita tersebut

- Peserta didik menceritakan sebuah cerita rakyat dengan bahasa sendiri didepan kelass

- Peserta didik memerankan tokoh dalam cerita rakyat didepan kelas dengan temannya 


\section{3) Kegiatan Akhir (10 menit)}

- Menyimpulkan materi untuk memantapkan pemahaman peserta didik

- Melakukan penilaian hasil belajar

- Memberikan penugasan untuk minggu depan

- Mengajak semua peserta didik berdoa

\section{c. Pengamatan}

Berdasarkan pengamatan dan observasi saat guru mengajar, yang menjadi permasalahan dalam pembelajaran tersebut adalah :

a) Peserta didik kurang termotivasi dalam pembelajaran

b) Nilai rerata kelas yang diperoleh 69 masih dibawah KKM yaitu 70 dan hasil pengamatan menunjukkan bahwa sebanyak $22(58 \%)$ peserta didik menjawab dengan benar

c) Tanggung jawab peserta didik akan tugas masih rendah,saat diberikan tugas belum dilaksanakan optimal

d) Media yang digunakan dalam pembelajaran belum maksimal

e) Keterlibatan peserta didik dalam kegiatan pembelajaran masih kurang.

\section{d. Refleksi}

Dalam pelaksanaan pembelajaran Siklus I, ditemukan kekuatan dan kelemahan dalam Tindakan Perbaikan Pembelajaran diantaranya:

1. Kekuatan

a) Pembelajaran lebih efektif dengan metode diskusi

b) Guru sudah melibatkan peserta didik dalam pembelajaran

c) Peserta didik mulai antusias terhadap media yang digunakan

d) Pemahaman materi oleh peserta didik sedikit lebih baik

2. Kelemahan

a) Guru kurang memandu peserta didik

b) Aktifitas peserta didik belum semua terlibat

c) Belum semua peserta didik mengerti tugasnya

d) Ruang kelas kurang kondusif karena masih ada anak yang sibuk dengan mengobrol

e) Pembelajaran masih didominasi peserta didik yang aktif saja 


\section{Siklus II}

\section{a. Persiapan}

1) Perencanaan pelaksanaan pembelajaran yang akan dilaksanakan pada hai Jum'at, tanggal 29 Juli 2019

2) Guru menyusun Rencana Pembelajaran Bahasa Indonesia dengan tema cerita rakyat

3) Penyusunan metode pembelajran berupa ceramah, dikusi, Tanya jawab, bermain peran dan penugasan

4) Persiapan sumber belajar dan bahan ajar berupa penayangan video cerita rakyat dan buku

5) Penyusunan alat evaluasi pembelajaran atau lembar kerja peserta didik (LKS).

\section{b. Pelaksanaan}

\section{1) Kegiatan Awal (10 menit)}

- Mengajak semua peserta didik berdoa menurut agama dan keyakinan masingmasing

- Melakukan komunikasi tentang kehadiran peserta didik / absen

- Mengkondisikan peserta didik dengan cara memotivasi dan membawa perhatian peserta didik agar tertuju pada materi pembelajaran dengan mengajukan beberapa pertanyaan yang mengacu pada materi yang akan diajarkan.

\section{2) Kegiatan Inti (50 Menit)}

- Guru menyajikan cerita rakyat ini melalui penayangan video cerita rakyat

- Siswa menyimak video sambil mendaftar nama tokoh dan watak tokoh dalam cerita tersebut

- Guru meminta peserta didik melakukan kegiatan bermain peran tentang cerita rakyat dengan cara tiap kelompok diwakilkan oleh satu orang anak untuk menceritakan cerita Malin Kundang.

- Melalui Tanya jawab guru dan peserta didik tentang cerita rakyat guru memberikan pertanyaan

\section{3) Kegiatan Akhir (10 menit)}

- Menyimpulkan materi untuk memantapkan pemahaman peserta didik

- Melakukan penilaian hasil belajar

- Memberikan penugasan untuk minggu depan 
- Mengajak semua peserta didik berdoa

\section{c. Pengamatan}

Peneliti melakukan pengamatan terhadap aktivitas peserta didik dalam mengikuti perbaikan pembelajaran dengan metode bermain peran.

Hasil pengamatan ternyata ada perubahan yang sangat berbeda karena peserta didik menjadi aktif, antusias, dan mengerti dengan jelas materi yag dipelajari. Hal ini berpengaruh dari hasil belajar yang meningkat dari siklus I ( rerata 69 ) ke siklus II ( naik rerata 80 ).

Hal ini dikarena guru sudah menggunakan media pembelajaran yang sesuai secara maksimal sehingga tidak terciptanya suasana pembelajaran yang kondusif dan menyenangkan bagi peserta didik.

a) Guru sudah menggunakan metode pembelajaran dan teknik pembelajaran yang bervariasi dan efektif

b) Guru sudah menggunakan media pembelajaran dan teknik pembelajaran yang bervariasi dan efektif

c) Guru sudah memberikan motivasi pada saat pembelajaran berlangsung sehingga peserta didik tertarik pada Bahasa Indonesia dengan tema cerita rakyat.

\section{d. Refleksi}

Dalam melakukan perbaikan pembelajaran, penulis dan teman sejawat mencatat beberapa hal yang sangat berpengaruh pada penerapan metode bermain peran (Role playing) melalui media penayangan video yaitu :

1) Dengan menggunakan metode Role Playing dan alat peraga LCD peserta didik mendapatkan suasana baru, sehingga dapat menghindari kebosanan dalam proses pembelajaran.

2) Dengan metode Role Playing, dapat membiasakan peserta didik untuk berkomunikasi aktif dalam bertukar pikiran dengan teman

3) Dengan metode Role Playing dan alat peraga LCD pada perbaikan pembelajaran pada siklus II ini hasil nilai rerata peserta didik sebesar 80. peserta didik yang tuntas dalam belajarnya sebanyak $30(80 \%)$ orang peserta didik atau yang belum tuntas sebanyak 8 orang peserta didik atau $20 \%$. 
4) Dengan Role Playing dan alat peraga LCD mendapatka keuntungan, menambah pengalaman dan kepercayaan diri,peserta didik. Pada akhirnya kualitas dan hasil belajar semakin membaik,sehingga tidak dilanjutkan dengan siklus berikutnya.

\section{Teknik Analisis Data}

Data yang telah dikumpulkan pada setiap kegiatan observasi dari pelaksanaan siklus penelitian dianalisis secara deskriptif dengan menggunakan teknik persentase untuk melihat kecenderungan yang terjadi dalam kegiatan pembelajaran mata pelajaran Bahasa Indonesia.

Dalam pelaksanaan penelitian ini membutuhkan dua siklus perbaikan untuk mata pelajaran Bahasa Indonesia. Pada proses perbaikan pembelajaran yang peneliti lakukan adalah melalui tiga tahap, yaitu diantaranya adalah : perencanaan, pelaksanaan, pengamatan dan refleksi.

Langkah-langkah dalam teknik analisis data yang dilakukan adalah sebagai berikut:

1) Melaksanakan kegiatan pembelajaran, yang terdiri dari kegiatan prasiklus, siklus I, dan siklus II

2) Mengumpulkan dan menganalisis nilai evaluasi pembelajaran dari tiap siklus dan mendeskripsikannya

3) Menentukan tingkat keberhasilan dan hasil evaluasi yang ditempuh dalam proses pembelajaran

4) Tes, yang digunakan untuk mendapatkan data tentang hasil belajar peserta didik

5) Observasi yang digunakan untuk mengumpulkan data tentang perkembangan keaktifan peserta didik dalam proses kegiatan belajar mengajar dengan menggunakan metode Role Playing

6) Diskusi dengan teman sejawat tentang keberhasilan dan kekurangan/kelemahan dalam pelaksanaan pembelajaran bermain peran dan alat peraga LCD dan merefleksikan hasil setiap siklus untuk perbaikan-perbaikan aktivitas dan praktek pembelajaran yang akan datang.

\section{V. HASIL PERBAIKAN DAN PEMBAHASAN}

\section{A. Deskripsi Hasil Penelitian Perbaikan Pembelajaran}

Penelitian Tindakan Kelas yang telah dilaksanakan untuk mata pelajaran Bahasa Indonesia di kelas V SDN Pasirgunung Selatan 4 Kota Depok yang dibantu 
dengan supervisor dalam menentukan kelemahan guru dan peserta didik sehingga dapat memberikan masukan terhadap perbaikan pelaksanaan pembelajaran.

Selain melaksanakan observasi, penulis juga melaksanakan refleksi pada proses belajar mengajar untuk menemukan langkah-langkah perbaikan pembelajaran. Dari hasil refleksi, ditemukan kekurangan peneliti dalam pembelajaran yang kurang tepatnya metode pembelajaran dan media pembelajaran yang digunakan, sehingga tidak sesuai dengan kebutuhan peserta didik.

Dari hasil observasi dan diskusi teman sejawat maka masalah yang menjadi faktor penyebab kurang optimalnya proses pembelajaran sehingga perlu dilakukan perbaikan.

Adapun beberapa masalah tersebut antara lain :

a) Rendahnya nilai prestasi belajar peserta didik yang dibawah KKM.

b) Peserta didik kurang memahami pelajaran Bahasa Indonesia tentang penjelasan guru dengan materi cerita rakyat.

c) Peserta didik dikelas V SDN Pasirgunung Selatan 4 cenderung pasif dan kurang tertarik pada pelajaran Bahasa Indonesia materi cerita rakyat.

d) Peserta didik sering tidak fokus disaat guru memberikan materi pelajaran.

e) Peserta didik tidak menjawab pertanyaan guru dengan benar.

Adapun faktor-faktor penyebab rendahnya aktivitas belajar dan kemampuan siswa pada materi cerita rakyat adalah :

a) Guru belum menggunakan metode dan media pembelajaran yang menarik.

b) Guru kurang memotivasi kepada peserta didik dalam proses pembelajaran.

c) Guru tidak melibatkan peserta didik ketika menjelaskan materi.

d) Guru terlalu cepat dalam menjelaskan materi.

Penulis juga membuat beberapa instrument sebagai berikut:

1) Lembar evaluasi tiap-tiap siklus dengan menulis rerata kelas

2) Instrument pengamatan peserta didik yang dapat atau tidak dapat menjawab pertanyaan guru

Berikut deskripsi data dari setiap kegiatan pembelajaran prasiklus, siklus 1, dan siklus 2 . 


\section{Prasiklus}

Pada pembelajaran prasiklus jumlah nilai keseluruhan adalah 2500 dengan rincian nilai tertinggi 100 dan nilai terendah adalah 20, hasil nilai rerata kelas 66. Peserta didik yang tuntas dalam belajar hanya berjumlah 20 orang dari 38 peserta didik atau 53\% dan yang belum mencapai ketuntasan belajar adalah 18 orang dari 38 peserta didik atau $47 \%$. Sedangkan hasil pengamatan menunjukkan bahwa sebanyak 17 orang dari 38 peserta didik menjawab dengan benar atau 45\%, dan yang belum menjawab dengan benar sebanyak 21 orang dari 38 peserta didik atau 55\%.

\section{Siklus 1}

Pada pembelajaran siklus 1 jumlah nilai keseluruhan adalah 2640 dengan nilai tertinggi yang dicapai peserta didik sebesar 100 dan nilai terendah 35 dengan nilai rata-rata 69. Peserta didik yang belum mencapai KKM adalah 16 orang dari 38 peserta didik atau $42 \%$ dan peserta didik yang telah mencapai ketuntasan sebanyak 22 dari 38 peserta didik atau sebesar $58 \%$. Sedangkan hasil pengamatan menunjukkan bahwa sebanyak 25 orang dari 38 peserta didik menjawab denga benar atau sebesar $66 \%$ dan yang belum menjawab dengan benar sebanyak 13 orang dari 38 peserta didik atau dengan kata lain $34 \%$.

\section{Siklus 2}

Pada siklus 2, perolehan jumlah nilai keseluruhan 3025 dengan perolehan nilai tertinggi 100 dan nilai terendah adalah 50. Rerata kelas diperoleh nilai 80 . Peserta didik yang tuntas dalam belajarnya sebanyak 30 orang dari 38 peserta didik atau $80 \%$. Sedangkan yang belum tuntas sebanyak 8 orang dari 38 peserta didik atau $20 \%$. Dari hasil pengamatan yang dapat menjawab dengan benar sebanyak 32 (84\%) dan belum menjawab dengan benar $6(16 \%)$ peserta didik.

Dengan dilaksanakannya kegiatan siklus 2 yang merupakan perbaikan dari siklussiklus sebelumnya, kemudian dilakukan evaluasi pembelajaran, ternyata nilai rerata peserta didik yang diperoleh mencapai 80. Setelah dilaksanakan perbaikan, kemudian dilakukan evaluasi pembelajaran, akhirnya dapat disajikan tabel rekapitulasi nilai hasil belajar dan pengamatan. Perbandingan perolehan nilai dari tiap-tiap siklus berbeda. Pada prasiklus nilai tertinggi 100, siklus satu 100, siklus dua 100. Perolehan rerata prasiklus 
66, siklus satu 69, siklus dua 80, begitu juga tingkat ketuntasan secara prosentase mengalami peningkatan. Prosentase pada prasiklus 47\%, siklus satu 58\%, siklus dua $80 \%$.

Tabel 11

Data Rekapitulasi Nilai Hasil Belajar Bahasa Indonesia

\begin{tabular}{|c|c|c|c|c|c|}
\hline \multirow{2}{*}{ NO } & \multirow{2}{*}{ NAMA } & \multirow{2}{*}{$\mathbf{L} / \mathbf{P}$} & \multicolumn{3}{|c|}{ NILAI } \\
\hline & & & PRASIKLUS & SIKLUS 1 & SIKLUS 2 \\
\hline 1 & Aldo Dian Prasetya & $\mathrm{L}$ & 80 & 90 & 90 \\
\hline 2 & Alma Al-Husna & $\mathrm{L}$ & 60 & 70 & 75 \\
\hline 3 & Alvin Haryadi & $\mathrm{L}$ & 70 & 70 & 80 \\
\hline 4 & Ari Sultan F & $\mathrm{L}$ & 20 & 35 & 50 \\
\hline 5 & Audrey Anissa & $\mathrm{P}$ & 70 & 75 & 75 \\
\hline 6 & Bagas Dwi Handoko & $\mathrm{L}$ & 80 & 90 & 75 \\
\hline 7 & Bayu Pratama Aji & $\bar{L}$ & 70 & 80 & 80 \\
\hline 8 & Dimas Setiawan & $\mathrm{L}$ & 50 & 40 & 50 \\
\hline 9 & Dyandra Afrisiyon & $\bar{L}$ & 50 & 70 & 65 \\
\hline 10 & Erlan Maulana & $\mathrm{L}$ & 70 & 80 & 80 \\
\hline 11 & Faradillah Dwi A & $\mathrm{P}$ & 60 & 65 & 80 \\
\hline 12 & Fathia Salwa S & $\mathrm{P}$ & 80 & 80 & 90 \\
\hline 13 & Muh. Ridho K & $\mathrm{L}$ & 50 & 50 & 80 \\
\hline 14 & Nailah Aulia Rusdah & $\mathrm{P}$ & 60 & 50 & 70 \\
\hline 15 & Nayla Frisca Yulian & $\mathrm{P}$ & 80 & 80 & 90 \\
\hline 16 & Nur Farida Agustina & $\mathrm{P}$ & 60 & 60 & 60 \\
\hline 17 & Rafy F Muhammad & $\mathrm{L}$ & 60 & 80 & 95 \\
\hline 18 & Raihan Luthfi Seto & $\mathrm{L}$ & 40 & 60 & 75 \\
\hline 19 & Ramdhan Surya S & $\mathrm{L}$ & 20 & 40 & 65 \\
\hline 20 & Rendra Abdul Zaky & $\mathrm{L}$ & 80 & 75 & 90 \\
\hline 21 & Resty Septiya W & $\mathrm{P}$ & 80 & 60 & 90 \\
\hline 22 & Rifdah Ayu Nabilah & $\mathrm{P}$ & 80 & 90 & 100 \\
\hline 23 & Sherina Lyana W & $\mathrm{P}$ & 100 & 90 & 90 \\
\hline 24 & Shintya Fateha Sari & $\mathrm{P}$ & 80 & 75 & 95 \\
\hline 25 & Siti Naurah Syifa & $\bar{P}$ & 80 & 80 & 90 \\
\hline 26 & Soraya Nur Larasati & $\mathrm{P}$ & 80 & 75 & 90 \\
\hline 27 & Syafina Fahira & $\mathrm{P}$ & 50 & 50 & 80 \\
\hline 28 & Syahidah F Puteri.A & $\mathrm{P}$ & 100 & 100 & 100 \\
\hline 29 & Widi Putri W & $\mathrm{P}$ & 90 & 90 & 100 \\
\hline 30 & Zahra Nur Ira R & $\mathrm{P}$ & 70 & 60 & 85 \\
\hline 31 & Zahra Radinka S & $\mathrm{P}$ & 80 & 90 & 90 \\
\hline 32 & Zatta Akbar M & $\mathrm{L}$ & 60 & 85 & 85 \\
\hline 33 & Siti Erlina Sari & $\mathrm{P}$ & 70 & 75 & 90 \\
\hline 34 & Casya Nurul.A & $\mathrm{P}$ & 60 & 60 & 60 \\
\hline 35 & Haissyal Ramadhan & $\bar{L}$ & 40 & 60 & 60 \\
\hline 36 & Amin Udin & $\mathrm{L}$ & 60 & 65 & 75 \\
\hline 37 & Valentinus & $\mathrm{L}$ & 50 & 40 & 50 \\
\hline 38 & Muh. Sandi Andana & $\overline{\mathrm{L}}$ & 60 & 50 & 80 \\
\hline & Jumlah & & 2500 & 2640 & 3025 \\
\hline & Nilai rata-rata & & 66 & 69 & 80 \\
\hline
\end{tabular}




\begin{tabular}{|c|c|c|c|}
\hline KKM & 70 & 70 & 70 \\
\hline Nilai terendah & 20 & 35 & 50 \\
\hline Nilai tertinggi & 100 & 100 & 100 \\
\hline
\end{tabular}

Tabel 12

Data Rekapitulasi Pengamatan Hasil Belajar Bahasa Indonesia

\begin{tabular}{|c|c|c|c|c|c|c|c|c|}
\hline \multirow{2}{*}{ No } & \multirow{2}{*}{ Nama } & \multirow{2}{*}{$\mathbf{L} / \mathbf{P}$} & \multicolumn{2}{|c|}{ Prasiklus } & \multicolumn{2}{|c|}{ Siklus 1} & \multicolumn{2}{|c|}{ Siklus 2} \\
\hline & & & TM & $\mathbf{M}$ & TM & $\mathbf{M}$ & TM & $\mathbf{M}$ \\
\hline 1 & Aldo Dian Prasetya & $\mathrm{L}$ & $\sqrt{ }$ & & $\sqrt{ }$ & & $\sqrt{ }$ & \\
\hline 2 & Alma Al-Husna & $\mathrm{L}$ & & $\sqrt{ }$ & & $\sqrt{ }$ & $\sqrt{ }$ & \\
\hline 3 & Alvin Haryadi & $\mathrm{L}$ & & $\sqrt{ }$ & & $\sqrt{ }$ & $\sqrt{ }$ & \\
\hline 4 & Ari Sultan F & $\mathrm{L}$ & & $\sqrt{ }$ & & $\sqrt{ }$ & $\sqrt{ }$ & \\
\hline 5 & Audrey Anissa & $\mathrm{P}$ & & $\sqrt{ }$ & $\sqrt{ }$ & & $\sqrt{ }$ & \\
\hline 6 & Bagas Dwi Handoko & $\mathrm{L}$ & $\sqrt{ }$ & & $\sqrt{ }$ & & $\sqrt{ }$ & \\
\hline 7 & Bayu Pratama Aji & $\mathrm{L}$ & $\sqrt{ }$ & & $\sqrt{ }$ & & $\sqrt{ }$ & \\
\hline 8 & Dimas Setiawan & $\mathrm{L}$ & & $\sqrt{ }$ & & $\sqrt{ }$ & $\sqrt{ }$ & \\
\hline 9 & Dyandra Afrisiyon & $\mathrm{L}$ & & $\sqrt{ }$ & & $\sqrt{ }$ & $\sqrt{ }$ & \\
\hline 10 & Erlan Maulana & $\mathrm{L}$ & $\sqrt{ }$ & & $\sqrt{ }$ & & $\sqrt{ }$ & \\
\hline 11 & Faradillah Dwi A & $\mathrm{P}$ & & $\sqrt{ }$ & $\sqrt{ }$ & & $\sqrt{ }$ & \\
\hline 12 & Fathia Salwa S & $\mathrm{P}$ & $\sqrt{ }$ & & $\sqrt{ }$ & & $\sqrt{ }$ & \\
\hline 13 & Muh. Ridho K & $\mathrm{L}$ & $\sqrt{ }$ & & $\sqrt{ }$ & & $\sqrt{ }$ & \\
\hline 14 & Nailah Aulia Rusdah & $\mathrm{P}$ & & $\sqrt{ }$ & & $\sqrt{ }$ & & $\sqrt{ }$ \\
\hline 15 & Nayla Frisca Yulian & $\mathrm{P}$ & $\sqrt{ }$ & & $\sqrt{ }$ & & $\sqrt{ }$ & \\
\hline 16 & Nur Farida Agustina & $\mathrm{P}$ & & $\sqrt{ }$ & & $\sqrt{ }$ & & $\sqrt{ }$ \\
\hline 17 & Rafy F Muhammad & $\mathrm{L}$ & $\sqrt{ }$ & & $\sqrt{ }$ & & $\sqrt{ }$ & \\
\hline 18 & Raihan Luthfi Seto & $\mathrm{L}$ & & $\sqrt{ }$ & & $\sqrt{ }$ & & $\sqrt{ }$ \\
\hline 19 & Ramdhan Surya S & $\mathrm{L}$ & & $\sqrt{ }$ & & $\sqrt{ }$ & & $\sqrt{ }$ \\
\hline 20 & Rendra Abdul Zaky & $\mathrm{L}$ & & $\sqrt{ }$ & $\sqrt{ }$ & & $\sqrt{ }$ & \\
\hline 21 & Resty Septiya W & $\mathrm{P}$ & $\sqrt{ }$ & & $\sqrt{ }$ & & $\sqrt{ }$ & \\
\hline 22 & Rifdah Ayu Nabilah & $\mathrm{P}$ & $\sqrt{ }$ & & $\sqrt{ }$ & & $\sqrt{ }$ & \\
\hline 23 & Sherina Lyana W & $\mathrm{P}$ & $\sqrt{ }$ & & $\sqrt{ }$ & & $\sqrt{ }$ & \\
\hline 24 & Shintya Fateha Sari & $\mathrm{P}$ & $\sqrt{ }$ & & $\sqrt{ }$ & & $\sqrt{ }$ & \\
\hline 25 & Siti Naurah Syifa & $\mathrm{P}$ & & $\sqrt{ }$ & $\sqrt{ }$ & & $\sqrt{ }$ & \\
\hline 26 & Soraya Nur Larasati & $\mathrm{P}$ & $\sqrt{ }$ & & $\sqrt{ }$ & & $\sqrt{ }$ & \\
\hline 27 & Syafina Fahira & $\mathrm{P}$ & & $\sqrt{ }$ & $\sqrt{ }$ & & $\sqrt{ }$ & \\
\hline 28 & Syahidah F Puteri.A & $\mathrm{P}$ & $\sqrt{ }$ & & $\sqrt{ }$ & & $\sqrt{ }$ & \\
\hline 29 & Widi Putri W & $\mathrm{P}$ & $\sqrt{ }$ & & $\sqrt{ }$ & & $\sqrt{ }$ & \\
\hline 30 & Zahra Nur Ira R & $\mathrm{P}$ & & $\sqrt{ }$ & & $\sqrt{ }$ & & $\sqrt{ }$ \\
\hline 31 & Zahra Radinka S & $\mathrm{P}$ & $\sqrt{ }$ & & $\sqrt{ }$ & & $\sqrt{ }$ & \\
\hline 32 & Zatta Akbar M & $\mathrm{L}$ & & $\sqrt{ }$ & $\sqrt{ }$ & & $\sqrt{ }$ & \\
\hline 33 & Siti Erlina Sari & $\mathrm{P}$ & $\sqrt{ }$ & & $\sqrt{ }$ & & $\sqrt{ }$ & \\
\hline 34 & Casya Nurul.A & $\mathrm{P}$ & & $\sqrt{ }$ & & $\sqrt{ }$ & $\sqrt{ }$ & \\
\hline 35 & Haissyal Ramadhan & $\mathrm{L}$ & & $\sqrt{ }$ & & $\sqrt{ }$ & $\sqrt{ }$ & \\
\hline 36 & Amin Udin & $\mathrm{L}$ & & $\sqrt{ }$ & $\sqrt{ }$ & & $\sqrt{ }$ & \\
\hline 37 & Valentinus & $\mathrm{L}$ & & $\sqrt{ }$ & & $\sqrt{ }$ & & $\sqrt{ }$ \\
\hline 38 & Muh. Sandi Andana & $\mathrm{L}$ & & $\sqrt{ }$ & $\sqrt{ }$ & & $\sqrt{ }$ & \\
\hline & JUMLAH & & 17 & 21 & 25 & 13 & 32 & 6 \\
\hline
\end{tabular}


Keterangan: $\mathrm{TM}=$ Tidak menjawab

$$
\mathrm{M}=\text { Menjawab }
$$

\section{B. Pembahasan Hasil Penelitian Perbaikan Pembelajaran}

Pada kegiatan prasiklus dengan menggunakan metode ceramah dan media pembelajaran papan tulis kemudian di evaluasi perolehan nilai rerata peserta didik pada pembelajaran prasiklus jumlah nilai keseluruhan keseluruhan adalah 2500 dengan rincian nilai tertinggi 100 dan nilai terendah adalah 20, hasil nilai rerata kelas 66. Peserta didik yang tuntas dalam belajar hanya berjumlah 20 orang dari 38 peserta didik atau $53 \%$ dan yang belum mencapai ketuntasan belajar adalah 18 orang dari 38 peserta didik atau $47 \%$. Sedangkan hasil pengamatan menunjukkan bahwa sebanyak 17 orang dari 38 peserta didik menjawab dengan benar atau 45\%, dan yang belum menjawab dengan benar sebanyak 21 orang dari 38 peserta didik atau 55\%. Hal ini tergambar dari tabel 2 dan 3.

Pada siklus 1, proses pembelajaran dikelas menggunakan metode ceramah, diskusi, dan bermain peran (role playing). Adanya peningkatan hasil belajar yang ditunjukkan dengan nilai rata-rata 69 dengan hasil pengamatan peserta didik yang dapat menjawab pertanyaan dengan benar sebesar $66 \%$ dan ketuntasan belajar sebesar 58\%. Akan tetapi, hasil yang diperoleh peserta didik masih belum mencapai KKM yang diharapkan. Oleh karena itu, peneliti melanjutkan perbaikan pada pembelajaran siklus 2 .

Nilai ini dapat disebabkan dari :

a) Rendahnya nilai prestasi belajar peserta didik yang dibawah KKM.

b) Peserta didik kurang memahami pelajaran Bahasa Indonesia tentang penjelasan guru dengan materi cerita rakyat.

c) Peserta didik dikelas V SDN Pasirgunung Selatan 4 cenderung pasif dan kurang tertarik pada pelajaran Bahasa Indonesia materi cerita rakyat.

d) Peserta didik sering tidak fokus disaat guru memberikan materi pelajaran.

e) Peserta didik tidak menjawab pertanyaan guru dengan benar.

Adapun faktor-faktor penyebab rendahnya aktivitas belajar dan kemampuan siswa pada materi cerita rakyat adalah :

a) Guru belum menggunakan metode dan media pembelajaran yang menarik.

b) Guru kurang memotivasi kepada peserta didik dalam proses pembelajaran.

c) Guru tidak melibatkan peserta didik ketika menjelaskan materi. 
d) Guru terlalu cepat dalam menjelaskan materi.

Penulis menemukan alternatif dan prioritas pemecahan masalah sebagai berikut :

e) Dalam penyampaian materi guru harus menggunakan metode dan media yang menarik, tepat, mudah dipahami agar pembelajaran jadi menyenangkan.

f) Guru harus dapat memotivasi terhadap seluruh peserta didik.

g) Guru harus melibatkan seluruh peserta didik dalam proses pembelajaran.

h) Dalam menjelaskan materi guru harus perlahan-lahan dan dapat dipahami peserta didik.

Pada pembelajaran siklus 2, peneliti menambahkan metode bermain peran dan media audio visual. Dari pelaksanaan evaluasi pada siklus 2 terjadi peningkatan hasil belajar yang signifikan yaitu diperoleh rata-rata 80 dengan pengamatan peserta didik yang dapat menjawab pertanyaan dengan benar sebesar $80 \%$ dan ketuntasan belajar sebesar $80 \%$. Penggunaan metode bermain peran dan media audio visual berpengaruh pada hasil belajar peserta didik. Hal ini dapat membantu kesulitan peserta didik dalam proses belajar sehingga dapat meningkatkan pemahaman peserta didik terhadap pembelajaran Bahasa Indonesia.

Dengan demikian penggunaan metode bermain peran dan media audio visual dapat meningkatkan prestasi belajar peserta didik kelas V SDN Pasirgunung Selatan 4 Kota Depok pada mata pelajaran Bahasa Indonesia Tema cerita rakyat. Berdasarkan hasil pembelajaran pada siklus 2 tersebut peneliti tidak perlu melakukan perbaikan pembelajaran pada siklus berikutnya.

\section{KESIMPULAN DAN SARAN TINDAK LANJUT}

\section{A. Simpulan}

Berdasarkan hasil Penelitian Tindakan Kelas (PTK) melalui aktivitas perbaikan pembelajaran yang telah dilaksanakan mulai dari prasiklus, siklus 1 smpai dengan siklus 2 pada mata pelajaran Bahasa Indonesia, penulis dapat menarik kesimpulan sebagai berikut:

1. Pada pembelajaran prasiklus diperoleh nilai rata-rata 66 , peserta didik yang tuntas dalam belajar hanya berjumlah $18(47 \%)$ peserta didik. Sedangkan hasil pengamatan menunjukkan bahwa sebanyak 21 (55\%) peserta didik dapat menjawab dengan benar. Pada siklus 1 nilai rata-rata 69. Peserta didik mencapai ketuntasan sebanyak 22 (58\%). Sedangkan hasil pengamatan menunjukkan bahwa sebanyak 25 (66\%) dapat menjawab dengan benar. Pada pembelajaran siklus 2, peneliti mencoba memperbaiki kekurangan pada saat siklus 1 selain menggunakan metode bermain peran (Role playing) juga 
menambahkan media audio visual. Pada siklus 2 diperoleh rerata kelas 80 . Pesera didik yang tuntas belajarnya sebanyak $30(80 \%)$ peserta didik. Peserta didik sedangkan hasil pengamatan yang dapat menjawab dengan benar pertanyaa guru sebanyak $32(84 \%)$

2. Dengan metode bermian peran dapat meningkatkan hasil belajar peserta didik secara signifikan pada pelajaran Bahasa Indonesia materi cerita rakyat dikelas V SDN Pasirgunung Selatan 4 Kecamatan Cimanggis Depok.

3. Dengan media audio visual dapat meningkatkan hasil belajar peserta didik pada pelajaran Bahasa Indonesia materi cerita rakyat dikelas V SDN Pasirgunung Selatan 4 Kecamatan Cimanggis Depok.

\section{B. Saran Tindak Lanjut}

Berdasarkan pada kesimpilan diatas ada beberapa hal yang sebaiknya dilakukan guru dalam upaya meningkatkan hasil belajar peserta didik.

1. Refleksi diri dalam perbaikan kemampuan pengajaran hendaknya sering dilakukan oleh seorang guru

2. Suasana belajar yang aktif didalam kelas akan memotivasi peserta didik dalam belajar

3. Penggunaan metode bermain peran dan media audio visual dapat membantu peseta didik untuk lebih cepat memahami konsep materi pelajaran. Dalam hal ini dapat menjadi alternative yang digunakan guru dalam mengajarkan pembelajaran Bahasa Indonesia

4. Memberikan kesempatan kepada peserta didik untuk lebih aktif dikelas, mengeluarkan pendapat untuk membubuhkan rasa percaya diri dan keberanian peserta didik dalam menjawab pertanyaan.

\section{DAFTAR PUSTAKA}

Achmad,. (2015).Buku Induk Mahir Bahasa dan Sastra Indonesia. Araska

Arsyad, Arsyad, \& Sulfemi, Wahyu Bagja. (2013). Pengaruh Persepsi Guru Tentang Kemampuan Manajerial Kepala Sekolah dan Kecerdasan Emosional Guru Terhadap Kinerja Guru (Studi Kasus Di SMK Muhammadiyah 6 Kabupaten Bogor). Fascho 2 (1), $1-9$

Anitah, S. (2014). Strategi Pembelajaran di SD. Jakarta: Universitas Terbuka

Asrori, Muhammad. (2009). Penelitian Tindakan Kelas. Bandung: CV Wacana Prima 
Chesler,M. (1966). Role Playing Methods in the classroom. Chicago: Science Research Associates

Daryanto. (2015). Media Pembelajaran. Bandung: PT Sarana Tutorial Nurani Sejahtera

Faturohman. (2015). Model-model pembelajaran inovatif Alternatif Desain pembelajaran yang menyenangkan. Yogyakarta: Ar. Russ Media

Fajartriani, Tia dan Sulfemi, Wahyu Bagja. (2014). Pengaruh Motivasi Kerja Guru dan Iklim Organisasi Terhadap Kinerja Guru SMA Negeri di Kecamatan Cigudeg. Edutecno. 8 (1), $17-26$

Heinich,dkk. (1990). Instructionak Media and The New Tecnologies of Instruction, john Wiley \& Sons, New York

Hopkins. (1993). Penelitian Tindakan Kelas. Tangerang Selatan: Universitas Terbuka

Mills. (2014). Penelitian Tindakan Kelas. Tangerang Selatan: Universitas Terbuka

Mulyati. (2015). Terampil Berbahasa Indonesia. Prenadamedia Group

Sudirman, Sudirman \& Sulfemi, Wahyu Bagja. (2010). Korelasi Antara Konsep Diri Guru dengan Profesionalisme Guru di SMA Negeri 1 Pamijahan Kabupaten Bogor. Edutecno $2(2), 10-19$

Sugiri, Sugiri \& Sulfemi, Wahyu Bagja. (2011). Pendidikan Multi Kultur di Sekolah Berbasis Keagamaan. Edutecno. 3 (2), 11-20.

Shaftel,F. (1967). Role Playing of Social Values: Decision makin in the social studies. Englewood Cliffs, N.J

Sulfemi, W. B. (2015). Pengaruh Metode Pembelajaran Kontekstual dan Penggunaan Media Video Pendidikan Terhadap Hasil Belajar IPS. Edutecno. 13 (2), 1, 10.

Sulfemi, Wahyu Bagja. (2019). Kompetensi Profesionalisme Guru Indonesia dalam Menghadapi MEA. Prosiding Seminar Nasional STKIP Muhammadiyah Bogor. 1 (1), 62-77.

Sulfemi, Wahyu Bagja. (2018). Hubungan Motivasi Belajar Dengan Hasil Belajar IPS Di SMP Kabupaten Bogor. Edutecno 18 (2), 1-8.

Sulfemi, Wahyu Bagja. (2018). Manajemen Kurikulum di Sekolah. Bogor : Visi Nusantara Maju.

Sulfemi, Wahyu Bagja dan Nurhasanah. (2018). Penggunaan Metode Demontrasi dan Media Audio Visual Dalam Meningkatkan Hasil Belajar Peserta Didik Mata Pelajaran IPS. Jurnal Pendas Mahakam. 3 (2). 151-158

Sulfemi, Wahyu Bagja dan Setianingsih. (2018), Penggunaan Tames Games Tournament (TGT) Dengan Media Kartu Dalam Meningkatkan Hasil Belajar. Journal of Komodo Science Education (JKSE. 1 (1), 1-14

Sulfemi, Wahyu Bagja. (2019). Manajemen Pendidikan Multi Kultur. Bogor : STKIP Muhammadiyah Bogor. 
Sulfemi, Wahyu Bagja. (2018). Pengaruh Disiplin Ibadah Sholat, Lingkungan Sekolah, dan Intelegensi Terhadap Hasil Belajar Peserta Didik Mata Pelajaran Pendidikan Agama Islam. Edukasi: Jurnal Penelitian Pendidikan Agama dan Keagamaan. 16 (2), 166-178.

Sulfemi, Wahyu Bagja dan Desmiati, Zulaicha. (2018). Model Pembelajaran Missouri Mathematics Project Berbantu Media Relief Experience dalam Meningkatkan Hasil Belajar Siswa. Jurnal Pendas Mahakam . 3 (3), 232-245.

Sulfemi, Wahyu Bagja dan Hilga Minati. (2018). Meningkatkan Hasil Belajar Peserta Didik Kelas 3 SD Menggunakan Model Picture And Picture dan Media Gambar Seri. JPSD. 4 (2), 228- 242 .

Sulfemi, Wahyu Bagja dan Mayasari, Nova. (2019). The Use of Audio Visual Media in Value Clarification Technique to Improvestudent Learning Outcomesin Social Studies. Jurnal Pendidikan. 20 (1), 53-68.

Sulfemi, Wahyu Bagja., \& Yuliana, Desi. (2019). Penerapan Model Pembelajaran Discovery Learning Meningkatkan Motivasi dan Hasil Belajar Pendidikan Kewarganegaraan. Jurnal Rontal Keilmuan Pancasila dan Kewarganegaraan. 5 (1), 17-30.

Sulfemi, Wahyu Bagja (2019). Model Pembelajaran Kooperatif Mind Mapping Berbantu Audio Visual Dalam Meningkatkan Minat, Motivasi dan Hasil Belajar IPS. Jurnal Pendidikan Ilmu Pengetahuan Sosial Indonesia (PIPSI). 4 (1), 13 - 19.

Sulfemi, Wahyu Bagja. (2019). Asosiatif Layanan Tenaga Perpustakaan Sekolah Dengan Motivasi Membaca Siswa di Kabupaten Bogor. Edutecno. 19 (2), 1-10.

Suprijono. (2019). Model-model Pembelajaran. Yogyakarta: Pustaka Belajar

Tarigan. (1992). Pendidikan Bahasa Indonesia, Jakarta: Depdikbud,hlm.21

Wardani, IGAK. (2014). Penelitian Tindakan Kelas. Tangerang Selatan: Universitas Terbuka 
